\title{
Analisis Kinerja Struktur pada Bangunan Bertingkat dengan Metode Analisis Respon Spektrum Berdasarkan SNI 1726:2019
}

\section{(Analysis of Structure Performance in Multistory Buildings with Response Spectrum Analysis Method Based on SNI 1726:2019)}

\author{
Muhammad Hilmi $^{1 *}$, Erizal ${ }^{1}$, dan Joana Febrita ${ }^{1}$ \\ ${ }^{1}$ Departemen Teknik Sipil dan Lingkungan, Fakultas Teknologi Pertanian, Institut Pertanian Bogor. \\ Jl. Raya Dramaga, Kampus IPB Dramaga, PO BOX 220, Bogor, Jawa Barat Indonesia \\ *Penulis korespondensi: muhammad_hilmi@apps.ipb.ac.id
}

Diterima: 9 Juli 2021

Disetujui: 31 Desember 2021

\begin{abstract}
The issuance of SNI 1726:2019 indicates that the planning has passed a certain transition period so that the existing regulations will no longer apply. Planning that has been made for Collaborative Research Center (CRC) buildings still uses regulations or standards that apply before. This study analyses the performance of structures in CRC buildings with spectrum response analysis methods based on SNI 1726:2019. The research method is carried out in several stages, starting from data collection, structure modelling, loading analysis, structure conformity analysis, and structure performance check. Modelling of CRC building structures is done based on as built drawing documents. Calculation of loading on building structures includes gravitational and lateral loads. The amount of mass participation obtained has been more than 90\%, while the value of the period of the structure and dynamic base shear force has been controlled to meet the requirements according to SNI 1726:2019. Based on the drift ratio value, the CRC building performance level is Immediate Occupancy $(I O)$. The result of checking the influence of P-Delta obtained $\theta$ value does not exceed the maximum $\theta$ value so that the CRC buildings can be said to be stable.
\end{abstract}

Keywords: earthquake, p-delta, shear force, spectrum response, story drift.

\section{PENDAHULUAN}

Pertumbuhan jumlah penduduk yang semakin bertambah dan perkembangan teknologi yang begitu pesat, menyebabkan kebutuhan akan ketersediaan infrastruktur juga semakin meningkat. Pembangunan infrastruktur sering kali terkendala dikarenakan minimnya lahan yang tersedia, sehingga dibutuhkan solusi untuk mengatasi permasalahan tersebut dengan memaksimalkan lahan yang tersedia yaitu membangun gedung-gedung bertingkat (Liando et al. 2020). Tingkat kerawanan suatu bangunan dalam menahan gaya lateral terutama gaya gempa berbanding lurus dengan ketinggian bangunan (Fauziah et al. 2013). Hal ini menjadi ancaman yang serius bagi konstruksi gedung di Kota Bogor dikarenakan letak Pulau Jawa yang berdekatan dengan zona subduksi lempeng Eurasia dan Indo-Australia.

Keadaan geografis yang menunjukkan ancaman yang cukup tinggi terhadap bencana gempa bumi menuntut konstruksi gedung di Kota Bogor harus direncanakan sebagai bangunan tahan gempa sehingga mampu menahan gaya aksial dan lateral yang akan terjadi. Bangunan tahan gempa harus direncanakan minimal dapat memberikan kinerja life safety, di mana struktur mengalami kerusakan sedang, namun tidak mencapai collapse 
prevention atau mengalami keruntuhan, sehingga timbulnya korban jiwa dapat diminimalisasi (Arifin et al. 2015).

Dalam perencanaan struktur bangunan di Indonesia, terdapat beberapa peraturan atau standar yang dapat dijadikan acuan. Terbitnya SNI 1726:2019 per tanggal 19 Desember 2019 menandakan bahwa perencanaan telah melewati masa transisi tertentu sehingga peraturan yang ada sebelumnya akan tidak berlaku lagi di kemudian hari. Salah satu bangunan bertingkat yang ada di Kota Bogor yaitu gedung Collaborative Research Center (CRC) yang diresmikan pada tanggal 4 Oktober 2019, sehingga dapat dikatakan bahwa perencanaan yang telah dibuat untuk gedung tersebut tentunya menggunakan peraturan atau standar yang berlaku sebelumnya.

Pemahaman terhadap SNI 1726:2019 sangat diperlukan dalam melakukan perencanaan bangunan bertingkat dikarenakan beban gempa yang bersifat tidak dapat diprediksi (Maulana et al. 2017). Analisis dinamik pada perencanaan bangunan tahan gempa dilakukan terhadap bangunanbangunan yang sangat tinggi atau bertingkat banyak, memiliki ketidakberaturan, serta bangunanbangunan yang membutuhkan ketelitian sangat besar di mana dapat memberikan pembagian gaya geser tingkat yang lebih tepat sepanjang tinggi gedung dibanding perencanaan analisis statik (Rendra et al. 2015). Perencanaan analisis dinamik dapat dilakukan dengan menggunakan metode analisis respon spektrum ataupun analisis riwayat waktu.

Penelitian yang dilakukan bertujuan untuk: (1) Melakukan pemodelan struktur gedung CRC dengan menggunakan perangkat lunak Autodesk Robot Structural Analysis (2) Menganalisis beban yang bekerja terhadap struktur gedung CRC (3)
Menganalisis kesesuaian struktur gedung CRC dengan menggunakan analisis respon spektrum yang meliputi partisipasi massa, periode fundamental, dan gaya geser dasar dalam memenuhi persyaratan berdasarkan SNI 1726:2019, dan (4) Mengevaluasi kinerja struktur gedung CRC terhadap simpangan antar tingkat dan pengaruh P-Delta berdasarkan SNI 1726:2019.

\section{METODOLOGI}

Penelitian ini dilaksanakan pada bulan Februari sampai dengan Juni 2021. Penelitian dilakukan dengan mengambil studi kasus pada gedung Collaborative Research Center (CRC) yaitu salah satu gedung yang didirikan di kawasan Science and Techno Park IPB di Taman Kencana, Bogor.

Alat yang digunakan adalah laptop yang dilengkapi perangkat lunak Autodesk Robot Structural Analysis 2021, Spektrum Respons Desain Indonesia 2021, AutoCAD 2021, dan Microsoft Office 2019. Adapun bahan yang digunakan dalam penelitian ini yaitu data sekunder berupa as built drawing gedung CRC, data penyelidikan tanah, serta data kondisi cuaca di sekitar lokasi bangunan.

Metode penelitian ini dilakukan dengan beberapa tahap, dimulai dari pengumpulan data, pemodelan struktur, analisis pembebanan, analisis kesesuaian struktur, dan cek kinerja struktur.

Pengumpulan data dari kontraktor meliputi dokumen as built drawing dan data penyelidikan tanah yang digunakan untuk mengetahui jenis tanah yang terdapat di sekitar lokasi bangunan, serta data kondisi cuaca berupa kecepatan angin dasar dan curah hujan di sekitar lokasi bangunan. Selain itu juga dilakukan pengumpulan peraturan yang akan digunakan sebagai acuan, di antaranya SNI 1726:2019, SNI 
1727:2020, SNI 2847:2019, Peta Sumber dan Bahaya Gempa Indonesia Tahun 2017, dan PPPURG 1987.

Pemodelan dilakukan dengan program Autodesk Robot Structural Analysis 2021 berupa struktur atas yang terdapat pada eksisting bangunan seperti kolom, balok, pelat, core wall, dan struktur rangka atap. Pemodelan elemen struktur akan dibentuk dalam perspektif arah tiga dimensi, yaitu sumbu X, Y, dan Z. Struktur bawah gedung atau pondasi dimodelkan dengan tumpuan jepit. Sementara itu, struktur atap dimodelkan tiga dimensi secara terpisah dengan tumpuan sendi.

Pembebanan yang dilakukan mengacu pada peraturan SNI 1727:2020, SNI 1726:2019, dan PPPURG 1987. Perencanaan pembebanan pada struktur ini mencakup beban mati (D), beban hidup (L), beban hidup atap $\left(\mathrm{L}_{\mathrm{r}}\right)$, beban hujan (R), beban angin (W), dan beban gempa (E). Beban mati meliputi beban gedung sendiri dan beban mati tambahan.

Penentuan desain respon spektrum gempa rencana dilakukan berdasarkan SNI 1726:2019. Nilai spektrum dipengaruhi oleh klasifikasi situs tanah, periode getar, rasio redaman, dan tingkat daktilitas. Klasifikasi situs tanah digunakan untuk menentukan besarnya nilai percepatan puncak dengan kemungkinan $2 \%$ terlampaui dalam 50 tahun. Faktor amplifikasi yang digunakan yaitu periode pendek pada 0,2 detik dan periode 1 detik yang dapat dilihat pada SNI 1726:2019 pasal 6.2. Besarnya nilai parameter yang akan digunakan untuk menentukan kurva desain respon spektrum dapat dihitung dengan persamaan (1)-(6).

$\mathrm{S}_{\mathrm{MS}}=\mathrm{F}_{\mathrm{a}} \mathrm{S}_{\mathrm{S}}$

$\mathrm{S}_{\mathrm{M} 1}=\mathrm{F}_{\mathrm{v}} \mathrm{S}_{1}$

$\mathrm{S}_{\mathrm{DS}}=\frac{2}{3} \times \mathrm{S}_{\mathrm{MS}}$
$\mathrm{S}_{\mathrm{D} 1}=\frac{2}{3} \times \mathrm{S}_{\mathrm{M} 1}$
$\mathrm{~T}_{0}=0,2 \frac{\mathrm{S}_{\mathrm{D} 1}}{\mathrm{~S}_{\mathrm{DS}}}$
$\mathrm{T}_{\mathrm{S}}=\frac{\mathrm{S}_{\mathrm{D} 1}}{\mathrm{~S}_{\mathrm{DS}}} \ldots \ldots \ldots \ldots . .$.

Keterangan:

$\mathrm{S}_{\mathrm{S}}=$ parameter percepatan batuan dasar periode pendek

$\mathrm{S}_{1}=$ parameter percepatan batuan dasar periode 1 detik

$\mathrm{F}_{\mathrm{a}}=$ faktor amplifikasi percepatan getaran periode pondek

$\mathrm{F}_{\mathrm{v}}=$ faktor amplifikasi percepatan yang mewakili getaran periode 1 detik

$\mathrm{S}_{\mathrm{MS}}=$ parameter percepatan gempa $\mathrm{MCE}_{\mathrm{R}}$ periode pendek

$\mathrm{S}_{\mathrm{M} 1}=$ parameter percepatan gempa MCE $_{\mathrm{R}}$ periode 1 detik

$\mathrm{S}_{\mathrm{DS}}=$ parameter respon spektra desain periode pendek

$\mathrm{S}_{\mathrm{D} 1}=$ parameter respon spektra desain periode 1 detik

$\mathrm{T}$ = periode getar fundamental struktur

$\mathrm{T}_{0}=$ waktu awal bangunan merespon beban gempa (detik)

$\mathrm{T}_{\mathrm{S}}=$ waktu tempuh untuk periode pendek (detik)

Analisis kesesuaian struktur didapatkan setelah melakukan running analysis pada pemodelan yang sudah sesuai dengan data perencanaan. Hasil yang didapatkan berupa partisipasi massa, periode fundamental, dan gaya geser dasar. Hasil tersebut dapat dikontrol dan dievaluasi dengan mengacu pada SNI 1726:2019, sehingga dapat diketahui apakah gedung CRC telah sesuai dengan syarat-syarat perencanaan berdasarkan SNI terbaru.

Partisipasi massa adalah besarnya rasio komponen struktur bangunan terhadap getaran yang dialami bangunan saat terjadi beban gempa (Harahap dan Fauzan 2019). Berdasarkan SNI 1726:2019, partisipasi massa 
disyaratkan harus menyertakan jumlah ragam yang cukup untuk mendapatkan partisipasi massa ragam terkombinasi sebesar $100 \%$ dari massa struktur atau diizinkan paling sedikitnya $90 \%$ dari massa aktual apabila tidak dapat mencapai $100 \%$.

Setiap struktur memiliki periode getar di mana struktur tersebut ingin bergerak/ bergetar/bergoyang ketika terjadi gangguan seperti beban angin atau gempa. Pada analisis dinamik, periode getar digambarkan dengan mode shape. Periode getar perlu dikontrol untuk menghindari penggunaan struktur yang terlalu fleksibel. Nilai periode minimum dan maksimum dapat dihitung dengan menggunakan persamaan (7) dan (8).

$\mathrm{T}_{\mathrm{a}}=\mathrm{C}_{\mathrm{t}}\left(\mathrm{h}_{\mathrm{n}}\right) \mathrm{x}$

$\mathrm{T}_{\max }=\mathrm{C}_{\mathrm{u}} \mathrm{T}_{\mathrm{a}}$

Keterangan:

$\mathrm{T}_{\mathrm{a}}=$ batas minimum periode (detik)

$\mathrm{T}_{\max }=$ batas maksimum periode (detik)

$\mathrm{C}_{\mathrm{t}}=$ koefisien $(0,0466$ untuk rangka beton pemikul momen)

$\mathrm{h}_{\mathrm{n}} \quad=$ ketinggian struktur di atas dasar sampai tingkat tertinggi struktur (m)

$\mathrm{x}=$ koefisien $(0,9$ untuk rangka beton pemikul momen)

$\mathrm{C}_{\mathrm{u}}=$ koefisien untuk batas atas pada periode yang dihitung (1,4 untuk $\left.\mathrm{S}_{\mathrm{D} 1} \geq 0,4\right)$

Gaya geser dasar adalah gaya lateral atau gaya desain total akibat dari beban gempa yang terjadi pada tingkat dasar, di mana akan didistribusikan ke semua tingkat secara vertikal sepanjang tinggi struktur sebagai gaya gempa lateral yang bekerja pada masing-masing tingkat bangunan (Cornelis et al. 2014). Gaya geser dasar statik yang terjadi dipengaruhi oleh berat seismik efektif (W) dan ketinggian di tiap lantai. Berat seismik efektif dihitung dengan menyertakan seluruh beban mati dan $25 \%$ beban hidup pada tiap lantai (BSN 2019a). Gaya geser dasar seismik (V) yang terjadi dapat dihitung dengan menggunakan persamaan (9).

Vstatik $=\mathrm{C}_{\mathrm{S}} \mathrm{x} \mathrm{W}$

Keterangan:

$\mathrm{C}_{\mathrm{S}}=$ koefisien respons seismik (SNI 1726:2019 pasal 7.8.1.1)

$\mathrm{W}=$ berat seismik efektif $(\mathrm{kN})$

Gaya geser dasar statik (Vstatik) digunakan untuk mengontrol nilai gaya geser dasar dinamik di mana besarnya gaya geser dasar dinamik yang didapat dari analisis respon spektrum disyaratkan harus lebih besar atau sama dengan $100 \%$ dari nilai gaya geser dasar statik (BSN 2019a). Jika nilai gaya geser dasar dinamik minimum tidak terpenuhi, maka diperlukan nilai faktor skala desain seperti pada persamaan (10).

Faktor skala $=\frac{100 \% \text { Vstatik }}{\text { Vdinamik }}$

Cek kinerja struktur dilakukan untuk mengetahui apakah struktur telah kuat menahan beban-beban yang terjadi terutama terhadap simpangan antar tingkat dan pengaruh P-Delta yang disebabkan oleh beban gempa. Bila telah memenuhi, maka perencanaan dan pembangunan gedung telah dilakukan dengan sangat baik dan gedung aman untuk digunakan hingga waktu yang telah direncanakan. Sedangkan bila tidak memenuhi, maka akan diberikan rekomendasi perkuatan struktur seperti metode concrete jacketing ataupun fyber reinforced polymer (FRP) sehingga gedung dapat berfungsi dengan baik.

Syarat kinerja batas ultimit struktur gedung ditentukan berdasarkan simpangan antar tingkat akibat pengaruh gempa rencana dalam kondisi struktur gedung di ambang keruntuhan sehingga 
dapat mencegah simpangan antar tingkat yang berlebihan. Simpangan antar tingkat $(\Delta)$ harus dihitung sebagai perbedaan simpangan pada pusat massa di atas dan di bawah tingkat yang ditinjau. Simpangan pusat massa di tingkat-x $(\delta x)$ dapat dihitung sesuai dengan persamaan (11).

$\delta x=\frac{\text { Cd. } \delta \mathrm{xe}}{\mathrm{Ie}}$

Keterangan:

Tabel 1 Simpangan Antar Tingkat Izin $\left(\Delta_{a}\right)$

\begin{tabular}{lccc}
\hline \multicolumn{1}{c}{ Tipe struktur } & \multicolumn{2}{c}{ Kategori risiko } \\
\cline { 2 - 4 } & I atau II & III & IV \\
\hline $\begin{array}{l}\text { Struktur, selain dari struktur dinding geser batu bata, 4 tingkat atau } \\
\text { kurang dengan dinding interior, partisi, langit-langit dan sistem }\end{array}$ & & & \\
$\begin{array}{l}\text { dinding eksterior yang telah didesain untuk mengakomodasi } \\
\text { simpangan antar tingkat }\end{array}$ & $0,025 \mathrm{~h}_{\mathrm{sx}}$ & $0,020 \mathrm{~h}_{\mathrm{sx}}$ & $0,015 \mathrm{~h}_{\mathrm{sx}}$ \\
$\begin{array}{l}\text { Struktur dinding geser kantilever batu bata } \\
\text { Struktur dinding geser batu bata lainnya }\end{array}$ & $0,010 \mathrm{~h}_{\mathrm{sx}}$ & $0,010 \mathrm{~h}_{\mathrm{sx}}$ & $0,010 \mathrm{~h}_{\mathrm{sx}}$ \\
Semua sistem struktur lainnya & $0,007 \mathrm{~h}_{\mathrm{sx}}$ & $0,007 \mathrm{~h}_{\mathrm{sx}}$ & $0,007 \mathrm{~h}_{\mathrm{s}}$ \\
Semun & $0,020 \mathrm{~h}_{\mathrm{sx}}$ & $0,015 \mathrm{~h}_{\mathrm{sx}}$ & $0,010 \mathrm{~h}_{\mathrm{sx}}$
\end{tabular}

$\mathrm{h}_{\mathrm{sx}}$ : tinggi tingkat di bawah tingkat $\mathrm{x}$

Sumber: BSN 2019a

Batasan deformasi berdasarkan level kinerja struktur yang ditetapkan oleh FEMA 365 dan ATC-40 disajikan pada Tabel 2.

Tabel 2 Batasan Deformasi Berdasarkan Level Kinerja Struktur

\begin{tabular}{|c|c|c|c|c|}
\hline \multirow{2}{*}{$\begin{array}{c}\text { Batasan } \\
\text { rasio } \\
\text { simpanga } \\
\text { n } \\
\end{array}$} & \multicolumn{4}{|c|}{ Level kinerja struktur } \\
\hline & $\mathrm{IO}$ & $\mathrm{DC}$ & LS & SS \\
\hline $\begin{array}{l}\text { Rasio } \\
\text { simpanga } \\
\mathrm{n} \text { total } \\
\text { maksimu } \\
\mathrm{m}\end{array}$ & 0,01 & $\begin{array}{l}0,01- \\
0,02\end{array}$ & 0,02 & $0,33 \frac{\mathrm{Vi}}{\mathrm{Pi}}$ \\
\hline $\begin{array}{l}\text { Rasio } \\
\text { simpanga } \\
\mathrm{n} \text { inelastis } \\
\text { maksimu } \\
\mathrm{m}\end{array}$ & $\begin{array}{c}0,00 \\
5\end{array}$ & $\begin{array}{c}0,005 \\
- \\
0,015\end{array}$ & $\begin{array}{c}\text { Tidak } \\
\text { dibata } \\
\text { si }\end{array}$ & $\begin{array}{l}\text { Tidak } \\
\text { dibata } \\
\text { si }\end{array}$ \\
\hline $\begin{array}{l}\text { i: gaya ge } \\
\text { tal pada la }\end{array}$ & $\because$ & ada 1 & $\mathrm{i} ; \mathrm{Pi}$ & $\begin{array}{l}\text { ya geser } \\
\text { acy; DC } \\
\text { collapse }\end{array}$ \\
\hline
\end{tabular}

$$
\begin{aligned}
\mathrm{Cd}= & \text { faktor pembesaran defleksi (SNI } \\
& 1726: 2019 \text { pasal 7.2.2) } \\
\delta \mathrm{xe}= & \text { simpangan di tingkat-x yang } \\
& \text { disyaratkan dan ditentukan sesuai } \\
& \text { dengan analisis elastis } \\
\mathrm{Ie}= & \text { faktor keutamaan gempa (SNI } \\
& 1726: 2019 \text { pasal 4.1.2) }
\end{aligned}
$$

Berdasarkan SNI 1726:2019, simpangan antar tingkat yang terjadi $(\Delta)$ tidak boleh melebihi simpangan antar tingkat izin $\left(\Delta_{\mathrm{a}}\right)$ yang nilainya ditentukan berdasarkan pada Tabel 1 sebagai berikut. 
0,1 . Koefisien stabilitas dapat dihitung dengan menggunakan rumus pada persamaan (12).

$\theta=\frac{\mathrm{P}_{\mathrm{x}} \Delta \mathrm{Ie}}{\mathrm{V}_{\mathrm{x}} \mathrm{h}_{\mathrm{sx}} \mathrm{C}_{\mathrm{d}}}$

Keterangan:

Px = beban aksial total pada dan di atas tingkat- $x$

$\Delta=$ simpangan antar tingkat ( $\mathrm{mm})$

$\mathrm{Vx}$ = gaya geser seismik yang bekerja antara tingkat-x dan $\mathrm{x}-1(\mathrm{kN})$

hsx $=$ tinggi tingkat di bawah tingkat- $x$ (mm)

Koefisien stabilitas $(\theta)$ tidak boleh melebihi koefisien stabilitas maksimum $(\theta \max )$ yang ditentukan pada persamaan (13) sebagai berikut.

$\theta \max =\frac{0,5}{\beta C_{d}}$

Keterangan:

$\beta=$ rasio kebutuhan geser terhadap kapasitas geser untuk tingkat antara tingkat dan $\mathrm{x}-1$. Diizinkan secara konservatif diambil sebesar 1,0

Pengaruh P-Delta akan menimbulkan momen kolom yang sangat besar sehingga akan berpengaruh terhadap kestabilan dan kapasitas kolom. P-Delta merupakan gejala yang terjadi pada struktur bangunan gedung yang fleksibel di mana story drift akibat beban gempa menimbulkan eksentrisitas beban gravitasi $(\mathrm{P})$ terhadap sumbu vertikal kolom sehingga menghasilkan momen internal tambahan yang dapat mempengaruhi momen hasil analisis orde pertama (Istiono dan Ramadhan 2020). Oleh karena itu, stabilitas dari suatu struktur perlu diperiksa akibat adanya pengaruh P-Delta ini, terutama pada bangunan yang memiliki lebih dari 10 lantai atau ketinggian di atas 40 meter. Jika $\theta$ lebih besar dari $\theta$ maksimum, struktur berpotensi tidak stabil dan harus didesain ulang ataupun dilakukan perbaikan struktur apabila terjadi pada bangunan eksisting.

\section{HASIL DAN PEMBAHASAN}

\section{Pemodelan Struktur Gedung}

Gedung CRC memiliki 6 lantai dengan 1 lantai merupakan lantai dasar dan 1 lantai yang digunakan sebagai ruang mesin lift. Luas lantai dasar bangunan gedung CRC sebesar 825,178 $\mathrm{m}^{2}$. Material yang digunakan yaitu beton dengan mutu K-300 untuk elemen struktur kolom, balok, pelat lantai, dan core wall. Pemodelan struktur utama dan atap gedung CRC dilakukan secara terpisah dengan menggunakan program Autodesk Robot Structural Analysis 2021 dan mengacu pada dokumen as built drawing kontraktor. Struktur bawah gedung atau pondasi dimodelkan dengan tumpuan jepit. Sementara itu, struktur atap dimodelkan tiga dimensi secara terpisah dengan tumpuan sendi. Hasil pemodelan struktur gedung dapat dilihat pada Gambar 1. 


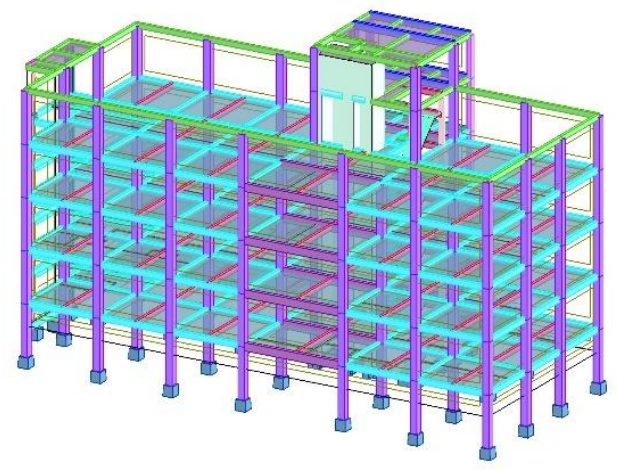

(a)

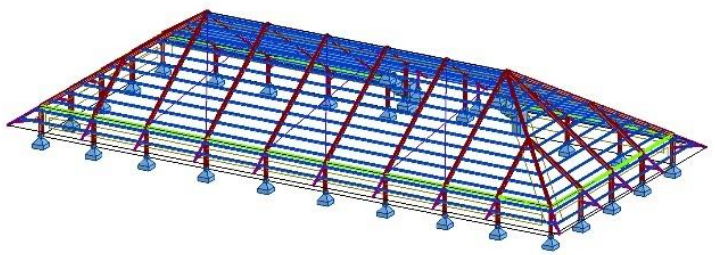

(b)

Gambar 1 Hasil Pemodelan 3D (a) Struktur Utama, (b) Struktur Atap

Struktur atap dibangun menggunakan sistem rangka baja yang memiliki 5 jenis frame kuda-kuda yang berbeda dan 1 jirai. Pemodelan struktur atap dilakukan dengan memodelkan rangka kuda-kuda atap, balok, purlin, dan juga bracing. Sedangkan sag rod dan penutup atap dijadikan beban yang didistribusikan secara merata. Jenis atap gedung CRC yaitu jenis atap perisai dengan penutup atap genteng keramik. Struktur atap memiliki sudut kemiringan sebesar $35^{\circ}$. Nilai pada reaksi tumpuan hasil analisis struktur atap nantinya dimasukkan ke dalam pemodelan struktur gedung utama sebagai beban titik pada ujung ruas ring balk.

\section{Pembebanan Struktur Gedung}

Pembebanan gravitasi meliputi beban mati, beban hidup, beban hidup atap, dan beban hujan. Beban gravitasi yang dimasukkan pada proses perhitungan mengacu pada SNI 1727:2020 dan PPPURG 1987. Selain beban gravitasi, terdapat juga beban lateral yang meliputi beban angin dan beban gempa. Kombinasi beban mengacu pada SNI 1726:2019 pasal 4.2.2 yaitu kombinasi beban untuk metode ultimit (ultimate limit state/ULS).

\section{Beban mati}

Beban mati dinyatakan sebagai berat dari semua bagian pada suatu bangunan yang terpasang secara tetap. Beban mati terdiri dari beban mati struktural (dead load) dan beban mati tambahan (super impossed dead load). Beban mati struktural terhitung secara otomatis pada program dengan mengkalkulasi volume elemen struktur sesuai dengan berat jenis material.

Berdasarkan BSN (2020), dapat diketahui besarnya beban mati tambahan pada masing-masing pelat lantai 1-4 sebesar $1,3 \mathrm{kN} / \mathrm{m}^{2}$, pelat atap dak beton sebesar $0,71 \mathrm{kN} / \mathrm{m}^{2}$, dan atap genteng sebesar $0,55 \mathrm{kN} / \mathrm{m}^{2}$ yang didistribusikan secara merata. Beban mati tambahan yang terjadi pada balok juga perlu diperhatikan karena struktur balok menahan beban garis seperti curtain wall kaca dan rangka sebesar $2,76 \mathrm{kN} / \mathrm{m}$, dinding pasangan bata ringan sebesar 2,62 kN/m, mortar untuk plesteran dan acian sebesar $1,48 \mathrm{kN} / \mathrm{m}$.

\section{Beban Hidup dan Beban Hidup Atap}

Beban hidup yang digunakan untuk desain struktur lantai, atap, dan bagian pendukungnya adalah beban terapan terbesar yang timbul dari penggunaan atau hunian yang 
diharapkan dari bangunan, atau dari penumpukan bahan dan penggunaan peralatan dan penyangga selama konstruksi, tapi tidak boleh kurang dari beban hidup minimum desain yang ditetapkan oleh standar (Kuddus dan Dey 2017). Beban hidup dan beban hidup atap yang digunakan pada gedung CRC mengacu pada SNI 1727:2020 dan disajikan pada Tabel 3.

Tabel 3 Beban Hidup dan Beban Hidup Atap

\begin{tabular}{lc}
\hline \multicolumn{1}{c}{ Jenis ruangan } & $\begin{array}{c}\mathrm{Beban}^{(\mathrm{a})} \\
\left(\mathrm{kN} / \mathrm{m}^{2}\right)\end{array}$ \\
\hline Ruang kantor & 2,40 \\
Laboratoium, toilet, ruang server/security & 2,87 \\
Koridor di atas lantai dasar & 3,83 \\
Tangga, ruang lobi, ruang meeting, ruang arsip, ruang rehat bersama, lobi lift, & 4,79 \\
pantry, musala & 6,00 \\
Janitor & 8,20 \\
Tangki air & 0,96 \\
\hline
\end{tabular}

(a) Beban area atau beban per satuan luas Sumber: BSN 2019a

Beban hidup akibat lift juga perlu diperhitungkan dengan meninjau beban reaksi yang berkaitan dengan mesin lift. Lift yang digunakan pada gedung CRC adalah lift penumpang yang diproduksi "Louser" dengan kapasitas 13 orang (900 kg) dan kapasitas 10 orang (680 $\mathrm{kg}$ ). Berdasarkan brosur Louser lift, didapatkan beban reaksi akibat ruang mesin lift pada lift dengan kapasitas 13 orang yaitu sebesar $5100 \mathrm{~kg}$ pada R1 dan $3800 \mathrm{~kg}$ pada R2, sedangkan pada lift dengan kapasitas 10 orang memiliki nilai R1 sebesar $4200 \mathrm{~kg}$ dan R2 sebesar 2850 kg. Beban-beban tersebut akan diterapkan sebagai beban titik di mana mesin lift ditempatkan.

Beban hidup atap berbubung $\left(\mathrm{L}_{0}\right)$ memiliki nilai sebesar $0,96 \mathrm{kN} / \mathrm{m}^{2}$. Beban tersebut harus direduksi sesuai dengan persyaratan pada SNI 1727:2020 pasal 4.8.2. Kemiringan atap dihitung dalam persentase dengan membagi nilai jarak vertikal dan horizontal pada atap, sehingga didapatkan nilai $R_{1}$ dan $R_{2}$ masing-masing yaitu 0,697 dan 0,788. Dengan mengalikan nilai tersebut dengan $\mathrm{L}_{0}$, beban hidup atap yang sudah direduksi $\left(\mathrm{L}_{\mathrm{r}}\right)$ dapat diketahui yaitu $0,527 \mathrm{kN} / \mathrm{m}^{2}$. Potongan melintang atap yang menunjukkan nilai jarak vertikal dan horizontal dapat dilihat pada Gambar 2.

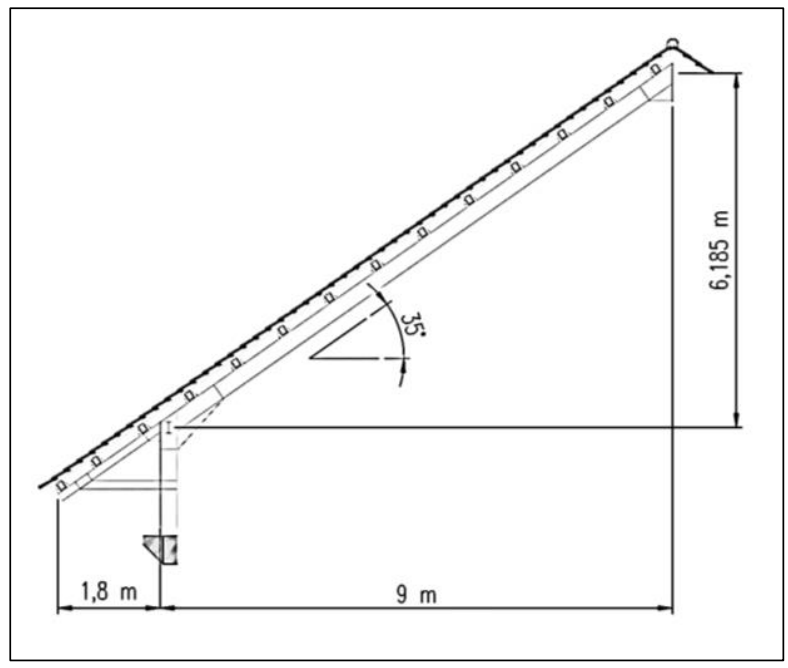

Gambar 2 Potongan Melintang Atap

\section{Beban Hujan}

Jenis atap gedung CRC yaitu jenis atap perisai yang memiliki nilai slope pada keempat sisinya sebesar $35^{\circ}$. Asumsi yang digunakan yaitu tinggi statis atau kedalaman air pada atap yang tidak melendut apabila sistem drainase primer tertutup setinggi $15 \mathrm{~mm}$ dan tinggi hidrolik atau tambahan kedalaman air pada atap yang tidak melendut pada aliran air rencana yaitu $10 \mathrm{~mm}$, sehingga 
didapatkan beban hujan (R) sebesar $0,245 \mathrm{kN} / \mathrm{m}^{2}$ yang didistribusikan secara merata pada bagian-bagian atap gedung CRC yang terkena hujan.

\section{Beban Angin}

Nilai kecepatan angin di Indonesia didasarkan pada peraturan HB 212-2002 mengenai kecepatan angin desain untuk wiayah Asia-Pasifik (Rudiyanto 2018). HB 212-2002 merekomendasikan nilai kecepatan angin desain menggunakan $\mathrm{v}_{\mathrm{s}}$ $=32 \mathrm{~m} /$ detik untuk serviceability design dan $\mathrm{v}_{\mathrm{s}}=40 \mathrm{~m} /$ detik untuk ultimate design di wilayah Indonesia. Dengan menggabungkan kemampuan analisis computational fluid dynamics (CFD) ke dalam program Autodesk Robot Structural Analysis 2021, nilai kecepatan angin yang dimasukkan dapat menghasilkan distribusi beban angin dengan arah $\mathrm{X}+, \mathrm{Y}+, \mathrm{X}-$, dan $\mathrm{Y}$ - secara otomatis pada struktur utama maupun atap (Marsh 2014).

\section{Desain Spektrum Gempa}

Respon spektrum merupakan grafik yang menggambarkan hubungan nilai puncak respon struktur percepatan akibat eksitasi gempa sebagai fungsi dari periode natural sistem struktur. Spektrum gempa dibuat berdasarkan SNI 1726:2019 dan Peta Sumber dan Bahaya Gempa Indonesia 2017. Pembuatan spektrum gempa disesuaikan dengan letak geografis dan jenis tanah (Fauzan et al. 2015).

\section{Penentuan Kelas Situs Tanah}

Klasifikasi kelas situs dapat ditentukan berdasarkan salah satu dari tiga parameter, yaitu parameter nilai kecepatan gelombang geser, atau nilai penetrasi standar (N-SPT), ataupun kuat geser niralir pada tanah dengan ketebalan 30 meter dari permukaan tanah (BSN 2019a). Berdasarkan perhitungan nilai N-SPT yang didapatkan dari penyelidikan tanah, didapatkan nilai $\bar{N}$ pada boring DB1 yaitu 18,177 dan nilai $\bar{N}$ pada boring DB2 yaitu 14,688 , sehingga didapatkan nilai $\bar{N}$ average sebesar 16,433. Hasil tersebut menunjukkan bahwa jenis tanah pada lokasi gedung CRC termasuk ke dalam kategori Tanah Sedang/SD. Karakteristik jenis tanah $\mathrm{D}$ adalah mempunyai nilai $\bar{N}$ yang berada pada interval $15<\bar{N}<50$ (BSN 2019a).

Gedung CRC secara geografis terletak pada koordinat $6^{\circ} 35^{\prime} 15,98^{\prime \prime} \mathrm{LS}$ dan $106^{\circ} 48^{\prime} 5,35^{\prime \prime}$ BT. Hasil analisis dari aplikasi Spektrum Respon Desain Indonesia 2021 diperoleh nilai percepatan batuan dasar 1 detik $\left(\mathrm{S}_{1}\right)$ sebesar $0,474 \mathrm{~g}$ dan nilai percepatan batuan dasar 0,2 detik $\left(\mathrm{S}_{\mathrm{S}}\right)$ sebesar $1,038 \mathrm{~g}$. Nilai $\mathrm{S}_{1}$ dan $\mathrm{S}_{\mathrm{S}}$ serta jenis tanah pada lokasi bangunan dijadikan acuan dalam menentukan nilai faktor amplifikasi terkait spektra percepatan. Semakin keras jenis tanah, nilai faktor amplifikasi terkait spektra percepatan akan semakin kecil, begitupun sebaliknya (Partono et al. 2013). Sehingga diperoleh nilai percepatan spektra periode 1 detik $\left(\mathrm{S}_{\mathrm{D} 1}\right)$ sebesar $0,577 \mathrm{~g}$ dan nilai percepatan spektra periode pendek $\left(\mathrm{S}_{\mathrm{DS}}\right)$ sebesar $0,751 \mathrm{~g}$. Kurva pada Gambar 3 menunjukkan besarnya percepatan spektra atau percepatan gempa yang terjadi pada tiga kondisi waktu yaitu sebelum $\mathrm{T}_{0}$, di antara $\mathrm{T}_{0}$ dan $\mathrm{T}_{\mathrm{S}}$, dan setelah $\mathrm{T}_{\mathrm{S}}$. 


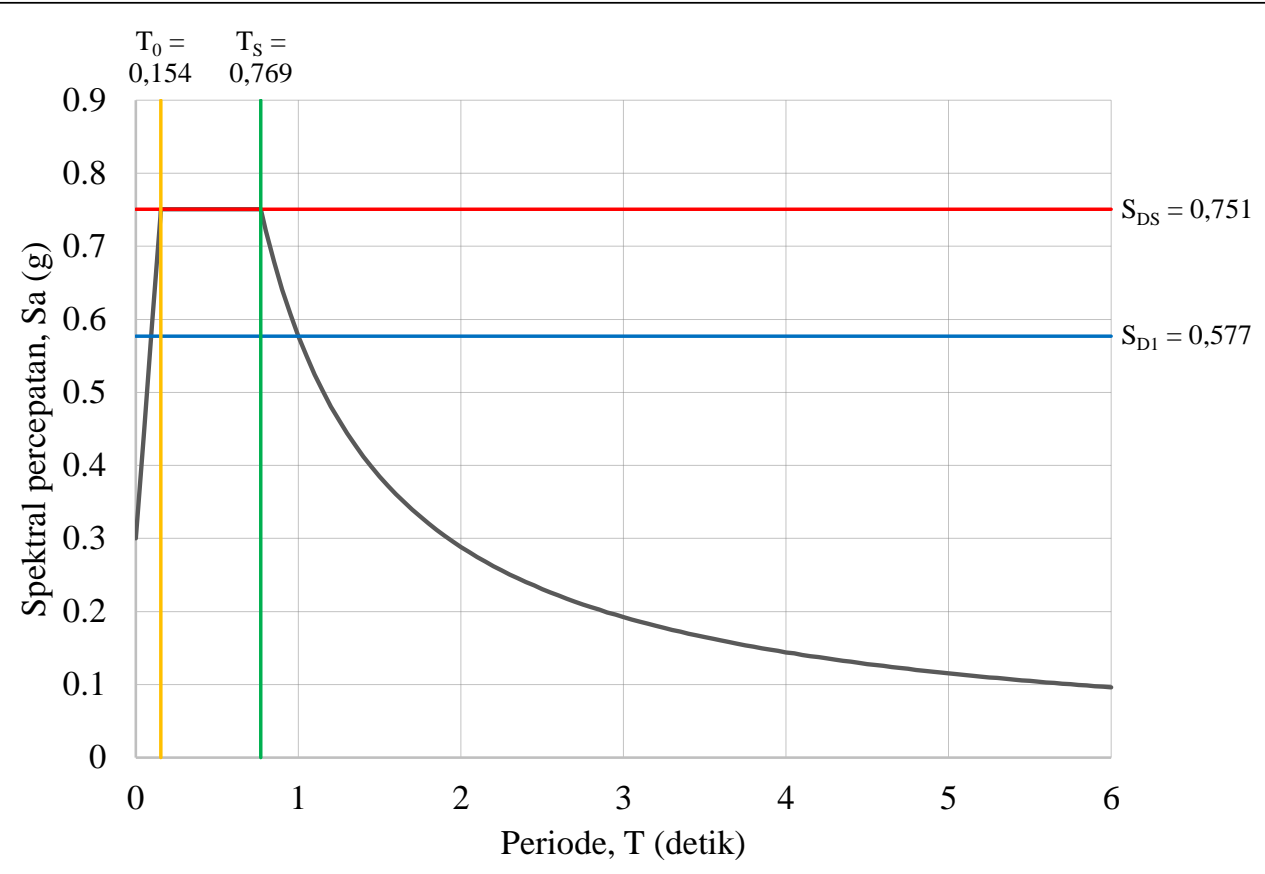

Gambar 3 Grafik Percepatan Respon Spektrum

\section{Sistem Rangka Pemikul Momen Khusus (SRPMK)}

Sistem penahan gaya gempa lateral yang digunakan yaitu Sistem Pemikul Rangka Momen Khusus (SRPMK). Penentuan tersebut berdasarkan kategori desain seismik (KDS) dan batasan tinggi struktur (hn). Kategori desain seismik ditujukan sebagai batasan dalam pemilihan sistem pemikul gaya seismik sehingga dapat memastikan pendetailan struktur yang memenuhi persyaratan sesuai dengan intensitas gempa yang diperkirakan. Berdasarkan SNI 1726:2019 pasal 7.2.2, struktur SRPMK memiliki nilai koefisien modifikasi respon $(\mathrm{R})$ sebesar 8, nilai faktor kuat lebih sistem $\left(\Omega_{0}\right)$ sebesar 3 , dan nilai faktor pembesaran defleksi $(\mathrm{Cd})$ sebesar 5,5 .

\section{Analisis Kesesuaian Struktur}

\section{Partisipasi Massa}

Partisipasi massa $90 \%$ menunjukkan hampir seluruh komponen struktur bangunan ikut bergetar apabila terjadi beban gempa sehingga dapat menyebabkan kerusakan terbesar. Apabila partisipasi massa yang diperoleh masih di bawah 90\%, maka jumlah ragam (mode) harus ditambah hingga memenuhi partisipasi massa minimum yang disyaratkan. Berdasarkan hasil program Autodesk Robot Structural Analysis 2021 yang disajikan pada Tabel 4, didapatkan partisipasi massa lebih dari 90\% untuk arah X maupun Y pada mode ke-24 masing-masing sebesar 92,08\% dan $90,25 \%$. Oleh karena itu, dapat disimpulkan bahwa struktur telah memenuhi syarat partisipasi massa yang tertera pada SNI 1726:2019. 
Tabel 4 Nilai Partisipasi Massa Arah X dan Y

\begin{tabular}{ccccccc}
\hline \multirow{2}{*}{ Mode } & Frekuensi & Periode & UX & UY & Kumulatif UX & Kumulatif UY \\
\cline { 2 - 7 } & (Hz) & $($ detik $)$ & $(\%)$ & $(\%)$ & $(\%)$ & $(\%)$ \\
\hline 1 & 1,07 & 0,94 & 10,88 & 2,35 & 10,88 & 2,35 \\
2 & 1,29 & 0,78 & 0,25 & 68,64 & 11,13 & 70,99 \\
3 & 1,73 & 0,58 & 62,65 & 0,01 & 73,78 & 71,00 \\
4 & 2,88 & 0,35 & 0 & 0,60 & 73,78 & 71,60 \\
5 & 3,21 & 0,31 & 1,02 & 0 & 74,80 & 71,60 \\
6 & 3,74 & 0,27 & 0,04 & 0,07 & 74,84 & 71,66 \\
7 & 3,78 & 0,26 & 0,16 & 3,65 & 75,00 & 75,31 \\
8 & 3,91 & 0,26 & 0,38 & 0,07 & 75,38 & 75,38 \\
9 & 4,15 & 0,24 & 0,75 & 0,58 & 76,13 & 75,96 \\
10 & 4,26 & 0,23 & 0 & 0,92 & 76,13 & 76,88 \\
11 & 4,38 & 0,23 & 0,12 & 0,01 & 76,25 & 76,90 \\
12 & 4,45 & 0,22 & 0,38 & 5,38 & 76,64 & 82,27 \\
13 & 4,59 & 0,22 & 0,88 & 0,13 & 77,51 & 82,40 \\
14 & 4,71 & 0,21 & 0,49 & 0,02 & 78,00 & 82,42 \\
15 & 4,75 & 0,21 & 0,21 & 0,54 & 78,21 & 82,96 \\
16 & 4,95 & 0,20 & 1,17 & 1,05 & 79,38 & 84,01 \\
17 & 5,10 & 0,20 & 0 & 1,00 & 79,38 & 85,00 \\
18 & 5,31 & 0,19 & 1,36 & 0,72 & 80,74 & 85,73 \\
19 & 5,40 & 0,19 & 2,46 & 1,84 & 83,20 & 87,57 \\
20 & 5,49 & 0,18 & 0 & 0,45 & 83,20 & 88,02 \\
21 & 5,71 & 0,18 & 3,45 & 0,16 & 86,65 & 88,18 \\
22 & 6,16 & 0,16 & 0,03 & 0 & 86,68 & 88,18 \\
23 & 6,26 & 0,16 & 2,11 & 0,86 & 88,79 & 89,04 \\
24 & 6,49 & 0,15 & 3,29 & 1,21 & 92,08 & 90,25 \\
25 & 6,73 & 0,15 & 0,04 & 0,01 & 92,12 & 90,26 \\
\hline
\end{tabular}

\section{Periode Fundamental Struktur}

Periode minimum dan maksimum yang diperoleh berdasarkan Tabel 5 masing-masing sebesar 0,897 detik dan 1,256 detik. Sedangkan hasil perhitungan periode arah $\mathrm{X}$ dan $\mathrm{Y}$ yang dihasilkan oleh pemodelan program Autodesk Robot Structural Analysis 2021 diperoleh masing-masing sebesar 0,58 detik dan 0,78 detik.

Tabel 5 Nilai Periode Getar Struktur (T)

\begin{tabular}{llll}
\hline Parameter & Nilai & Parameter & Nilai \\
\hline Tcx & 0,580 & Tcy & 0,780 \\
Ta & 0,897 & Ta & 0,897 \\
Tmax & 1,256 & Tmax & 1,256 \\
Tx & 0,897 & Ty & 0,897 \\
\hline
\end{tabular}

Tc: periode computed; Ta: periode minimum; Tmax: periode maksimum; $\mathrm{T}$ : periode desain

Nilai periode hitung $(\mathrm{Tc})$ berada di bawah periode minimum $\left(\mathrm{T}_{\mathrm{a}}\right)$ sehingga periode struktur desain ( $\mathrm{T}$ ) yang digunakan adalah periode fundamental pendekatan $\left(\mathrm{T}_{\mathrm{a}}\right)$ yang merupakan batas minimum periode sebesar 0,897 detik.

\section{Gaya Geser Dasar}

Nilai W (berat seismik efektif) diperoleh melalui output analisis pemodelan program Autodesk Robot Structural Analysis 2021 yaitu 3.641,02 ton. Berdasarkan Tabel 6, nilai $\mathrm{C}_{\mathrm{S}}$ desain yang digunakan yaitu nilai $\mathrm{C}_{\mathrm{S}}$ maksimum sebesar 0,1205 dikarenakan nilai koefisien respons seismik hitung ( $\mathrm{C}_{\mathrm{S}}$ hitung) melebihi nilai $\mathrm{C}_{\mathrm{S}}$ maksimum. Dengan menggunakan persamaan (9), maka nilai gaya geser dasar statik (Vstatik) arah gempa $\mathrm{X}$ dan $\mathrm{Y}$ dapat diperoleh yaitu sebesar 4.304,18 kN.

Tabel 6 Nilai Koefisien Sesmik $\left(\mathrm{C}_{\mathrm{S}}\right)$

\begin{tabular}{lclc}
\hline Parameter & Nilai & Parameter & Nilai \\
\hline $\mathrm{C}_{\mathrm{S}}$ hitung & 0,1408 & $\mathrm{C}_{\mathrm{S}}$ hitung & 0,1408 \\
$\mathrm{C}_{\mathrm{Sx}}$ maks & 0,1205 & $\mathrm{C}_{\mathrm{Sx}}$ maks & 0,1205 \\
$\mathrm{C}_{\mathrm{Sx}}$ min & 0,05 & $\mathrm{C}_{\mathrm{Sx}}$ min & 0,05 \\
$\mathrm{C}_{\text {Sx }}$ desain & 0,1205 & $\mathrm{C}_{\mathrm{Sx}}$ desain & 0,1205 \\
\hline
\end{tabular}


Berdasarkan hasil analisis pada program Autodesk Robot Structural Analysis 2021 dengan menggunakan metode analisis respons spektrum, nilai gaya geser dasar dinamik (Vdinamik) arah gempa $\mathrm{X}$ didapatkan sebesar $3.218,28 \mathrm{kN}$ dan arah gempa $\mathrm{Y}$ sebesar $3.453,07 \mathrm{kN}$. Nilai tersebut masih lebih kecil dari $100 \%$ nilai gaya geser dasar statik. Oleh karena itu, diperlukan suatu nilai faktor skala desain agar nilai gaya geser dasar dinamik minimum terpenuhi. Faktor skala untuk arah gempa X dan Y masing-masing sebesar 1,34 dan 1,25, sehingga diperoleh nilai gaya geser dasar dinamik (Vdinamik) untuk arah gempa $\mathrm{X}$ dan $\mathrm{Y}$ masing-masing sebesar 4.306,02 kN dan 4.305,98 kN. Distribusi gaya geser tingkat (story shear) statik, dinamik, dan koreksi yang telah memperhitungkan faktor skala dapat dilihat pada Gambar 4 dan 5.

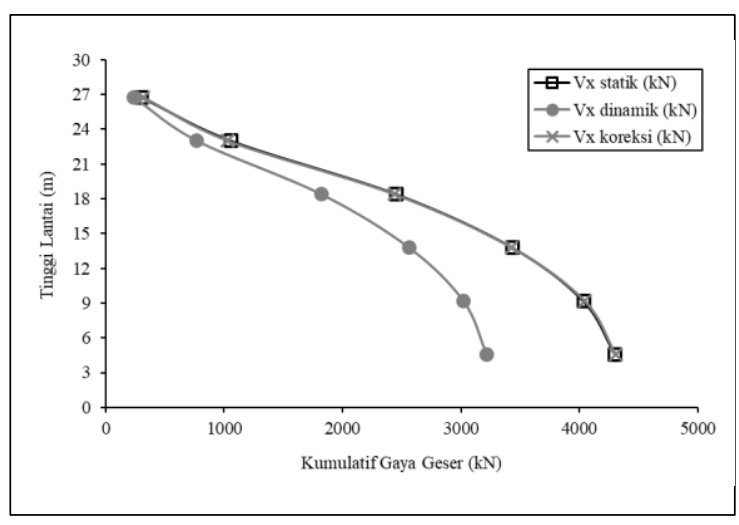

Gambar 4 Distribusi Gaya Geser Tingkat Pada Arah X

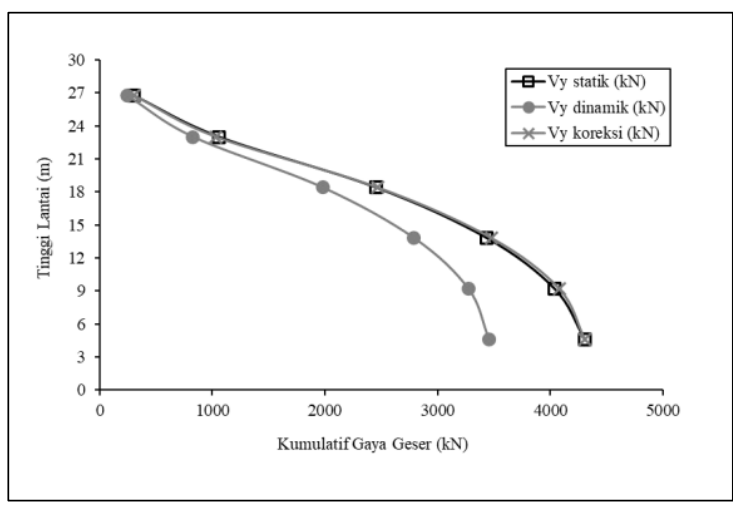

Gambar 5 Distribusi Gaya Geser

Tingkat Pada Arah Y
Berdasarkan Gambar 4 dan 5, Vdinamik yang telah dikoreksi memiliki nilai yang tidak berbeda jauh dibandingkan dengan Vstatik, di mana nilai persentase Vdinamik koreksi dan Vstatik pada arah $\mathrm{X}$ dan $\mathrm{Y}$ masingmasing adalah 100,043\% dan 100,042\%. Nilai tersebut sudah memenuhi nilai yang disyaratkan berdasarkan SNI 1726:2019 yaitu Vdinamik harus memiliki nilai minimal $100 \%$ dari Vstatik.

\section{Cek Kinerja Struktur}

\section{Simpangan Antar Tingkat}

Gaya lateral yang berupa beban angin dan beban gempa pada struktur bangunan harus dipertimbangkan dikarenakan gaya lateral dapat menimbulkan simpangan antar tingkat (story drift). Simpangan antar tingkat yang terjadi akan semakin besar apabila ketinggian sebuah gedung semakin tinggi, terutama pada lantai paling atas.

Gedung CRC yang berfungsi sebagai fasilitas pendidikan dan laboratorium dengan kategori risiko IV memiliki nilai batas simpangan antar tingkat yang diizinkan adalah sebesar $0,010 h_{\text {sx }}$ dengan nilai $h_{s x}$ adalah tinggi di bawah tingkat. Hasil perhitungan program Autodesk Robot Structural Analysis 2021 disajikan pada Tabel 7 dan 8, di mana nilai simpangan diambil dari hasil analisis yang terbesar dan paling berpengaruh yaitu pada $\mathrm{EQ}_{\mathrm{x}}$ untuk arah $\mathrm{X}$ dan $\mathrm{EQ}_{\mathrm{y}}$ untuk arah $\mathrm{Y}$ struktur gedung. 
Tabel 7 Perhitungan story drift dari Kinerja Batas Ultimit Arah X

\begin{tabular}{ccccccc}
\hline \multirow{2}{*}{ Lantai } & $\begin{array}{c}\text { Tinggi } \\
\text { tingkat }\end{array}$ & $\begin{array}{c}\text { Perpindahan } \\
\text { elastis }\end{array}$ & $\begin{array}{c}\text { Perpindahan } \\
\text { diperbesar }\end{array}$ & Story drift & Story drift izin & $\begin{array}{c}\text { Statu } \\
\text { s }\end{array}$ \\
\cline { 2 - 5 } & hsx $(\mathrm{mm})$ & $\delta$ ex $(\mathrm{mm})$ & $\delta \mathrm{x}(\mathrm{mm})$ & $\Delta \mathrm{x}(\mathrm{mm})$ & $\Delta \mathrm{a}(\mathrm{mm})$ & \\
\hline 1 & 4600 & 3,19 & 11,70 & 11,70 & 46,00 & aman \\
2 & 4600 & 8,62 & 31,61 & 19,91 & 46,00 & aman \\
3 & 4600 & 14,42 & 52,87 & 21,27 & 46,00 & aman \\
4 & 4600 & 19,80 & 72,60 & 19,73 & 46,00 & aman \\
5 & 4600 & 22,35 & 81,95 & 9,35 & 46,00 & aman \\
Ruang & 3750 & 23,99 & 87,96 & 6,01 & 37,50 & aman \\
mesin & & & & & & \\
\hline
\end{tabular}

Tabel 8 Perhitungan story drift dari Kinerja Batas Ultimit Arah Y

\begin{tabular}{ccccccc}
\hline \multirow{2}{*}{ Lantai } & $\begin{array}{c}\text { Tinggi } \\
\text { tingkat }\end{array}$ & $\begin{array}{c}\text { Perpindahan } \\
\text { elastis }\end{array}$ & $\begin{array}{c}\text { Perpindahan } \\
\text { diperbesar }\end{array}$ & Story drift & Story drift izin & $\begin{array}{c}\text { Statu } \\
\text { s }\end{array}$ \\
\cline { 2 - 5 } & hsx $(\mathrm{mm})$ & $\delta$ ey $(\mathrm{mm})$ & $\delta \mathrm{y}(\mathrm{mm})$ & $\Delta \mathrm{y}(\mathrm{mm})$ & $\Delta \mathrm{a}(\mathrm{mm})$ & aman \\
1 & 4600 & 3,88 & 14,23 & 14,23 & 46,00 & aman \\
2 & 4600 & 11,47 & 42,06 & 27,83 & 46,00 & aman \\
3 & 4600 & 20,48 & 75,09 & 33,04 & 46,00 & aman \\
4 & 4600 & 29,43 & 107,91 & 32,82 & 46,00 & aman \\
5 & 4600 & 37,79 & 138,56 & 30,65 & 46,00 & aman \\
Ruang & 3750 & 46,39 & 170,10 & 31,53 & 37,50 & \\
mesin & & & & & &
\end{tabular}

Nilai story drift maksimum yang diperoleh dari kinerja batas ultimit pada gedung CRC untuk arah $\mathrm{X}$ dan $\mathrm{Y}$ masing-masing yaitu $21,27 \mathrm{~mm}$ dan $33,04 \mathrm{~mm}$ yang terjadi pada lantai 3 . Nilai simpangan antar lantai (story drift) pada arah $\mathrm{X}$ dan $\mathrm{Y}$ untuk lantai 1 hingga lantai ruang mesin dinyatakan aman karena nilai story drift pada lantai tersebut lebih kecil dari nilai story drift izin. Hasil tersebut menyatakan bahwa struktur gedung CRC sudah memenuhi persyaratan keamanan terhadap kinerja batas ultimit yang dihitung berdasarkan SNI 1726:2019.

Perbandingan antara rasio simpangan arah $\mathrm{X}$ dan $\mathrm{Y}$ terhadap rasio simpangan izin dalam bentuk grafik disajikan pada Gambar 6. Dari nilai drift ratio yang diperoleh dan dibandingkan dengan batasan deformasi level kinerja struktur berdasarkan FEMA 365 dan ATC-40, dapat disimpulkan bahwa level kinerja struktur adalah Immediate Occupancy (IO). Hal ini dikarenakan drift ratio struktur yang terjadi pada arah
$\mathrm{X}$ dan $\mathrm{Y}$ lebih kecil dari $1 \%$, yaitu batas simpangan yang disyaratkan untuk level kinerja Immediate Occupancy (IO).

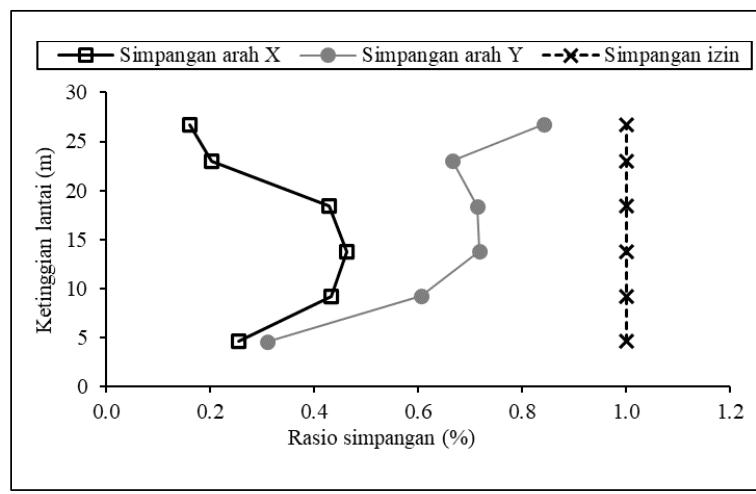

Gambar 6 Perbandingan Nilai Rasio Simpangan Arah X dan Y terhadap Simpangan Izin

\section{Pengaruh P-Delta}

Penambahan berat struktur akan memperbesar pengaruh P-Delta. Hal ini disebabkan berat strutur akan mempengaruhi besarnya gaya geser gempa (V) dan gaya aksial (P) (Avinash dan Pandian 2017). Berdasarkan persamaan (45), nilai $\theta \max$ diperoleh 
sebesar 0,09. Perhitungan nilai pengaruh P-Delta pada arah $\mathrm{X}$ dan $\mathrm{Y}$ dapat dilihat pada Tabel 9 dan 10 .

Tabel 9 Perhitungan Nilai Pengaruh PDelta Arah X

\begin{tabular}{ccccc}
\hline Lantai & $\mathrm{P}$ & $\mathrm{Vx}$ & \multirow{2}{*}{$0 \mathrm{x}$} & Status \\
\cline { 2 - 4 } $\begin{array}{c}\text { Ruang } \\
\text { mesin }\end{array}$ & 1170,4 & 314,8 & 0,002 & aman \\
5 & 5884,2 & $\begin{array}{c}1031, \\
9\end{array}$ & 0,003 & aman \\
& 18556, & 2437, & 0,009 & aman \\
4 & 3 & 5 & & \\
& 31342, & 3428, & 0,012 & aman \\
3 & 8 & 6 & & \\
& 44135, & 4043, & 0,013 & aman \\
2 & 6 & 4 & & \\
& 58873, & 4306, & 0,010 & aman \\
\hline
\end{tabular}

Tabel 10 Perhitungan Nilai Pengaruh PDelta Arah Y

\begin{tabular}{ccccc}
\hline \multirow{2}{*}{ Lantai } & $\mathrm{P}$ & $\mathrm{Vy}$ & \multirow{2}{*}{$\theta \mathrm{y}$} & Status \\
\cline { 2 - 4 } Ruang & $(\mathrm{kN})$ & $(\mathrm{kN})$ & & \\
mesin & 1170,4 & 301,5 & 0,009 & aman \\
5 & 5884,2 & $\begin{array}{c}1031, \\
3\end{array}$ & 0,010 & aman \\
& 18556, & 2467, & 0,015 & aman \\
4 & 3 & 8 & & \\
& 31342, & 3478, & 0,018 & aman \\
3 & 8 & 2 \\
5 & 44135, & 4078, & 0,018 & aman \\
2 & 6 & 1 & & \\
1 & 58873, & 4306, & 0,012 & aman \\
\hline
\end{tabular}

Berdasarkan Tabel 30 dan 31, hasil pengecekan terhadap pengaruh $\mathrm{P}$-Delta arah $\mathrm{X}$ dan Y pada struktur gedung CRC sudah sesuai dengan ketentuan yang disyaratkan di mana nilai $\theta$ tidak melebihi dari nilai $\theta$ maks sebesar 0,09, di mana story drift dan story shear yang timbul akibat pengaruh P-Delta perlu diperhitungkan atau struktur gedung CRC dapat dikatakan stabil terhadap beban gempa yang terjadi dan tidak perlu dilakukan perbaikan struktur.

\section{KESIMPULAN}

Pemodelan struktur gedung Collaborative Research Center (CRC) telah berhasil dilakukan secara tiga dimensi berdasarkan dokumen as built drawing kontraktor dan data pendukung lainnya. Perhitungan pembebanan terhadap struktur gedung meliputi beban mati, beban hidup, beban hidup atap, beban hujan, dan beban angin yang mengacu pada SNI 1727:2020 dan PPPURG 1987. Sedangkan beban gempa dan kombinasi pembebanan yang digunakan mengacu pada SNI 1726:2019.

Besarnya partispasi massa yang memenuhi $90 \%$ untuk arah X maupun $\mathrm{Y}$ terdapat pada mode ke-24 masingmasing sebesar 92,08\% dan 90,25\%. Periode struktur desain (T) yang digunakan yaitu 0,897 detik dikarenakan nilai periode hitung (Tc) berada di bawah periode minimum $\left(\mathrm{T}_{\mathrm{a}}\right)$. Pengecekan Vdinamik arah $\mathrm{X}$ dan $\mathrm{Y}$ yang telah dikalikan dengan faktor skala masing-masing sebesar 1,34 dan 1,25 telah memenuhi persyaratan sesuai SNI 1726:2019, di mana nilai Vdinamik koreksi yaitu 4.306,02 kN untuk arah $\mathrm{X}$ dan 4.305,98 kN untuk arah Y.

Nilai simpangan antar lantai pada arah X dan Y untuk lantai 1 hingga lantai ruang mesin dinyatakan aman karena simpangan antar lantai pada tiap lantai lebih kecil dari nilai simpangan izin. Berdasarkan nilai rasio simpangan arah $\mathrm{X}$ dan $\mathrm{Y}$, level kinerja struktur gedung CRC adalah Immediate Occupancy (IO). Hal ini dikarenakan rasio simpangan struktur yang terjadi lebih kecil dari $1 \%$. Hasil pengecekan terhadap pengaruh $\mathrm{P}$ Delta arah X dan Y pada struktur gedung CRC sudah sesuai dengan ketentuan yang disyaratkan di mana nilai $\theta$ tidak melebihi $\theta$ maks atau struktur gedung CRC dapat dikatakan stabil terhadap 
beban gempa yang terjadi dan tidak perlu dilakukan perbaikan struktur.

\section{DAFTAR PUSTAKA}

Arifin Z, Suyadi, Sebayang S. 2015. Analisis struktur gedung POP hotel terhadap beban gempa dengan metode pushover analysis. Jurnal Rekayasa Sipil dan Desain. 3(3):427-440.

[ATC] Applied Technology Council. 1996. Seismic Evaluation and Retrofit of Concrete Building Volume 1. ATC-40. California (US): ATC.

Avinash T, Pandian GAM. 2017. Investigation of the effects of $\mathrm{p}$ delta on tubular tall buildings. International Journal of Civil Engineering and Technology. 8(2):487-495.

[BSN] Badan Standardisasi Nasional. 2020. Beban Desain Minimum dan Kriteria Terkait untuk Bangunan Gedung dan Struktur Lain. SNI 1727:2020. Jakarta (ID): BSN.

[BSN] 2019a. Tata Cara Perencanaan Ketahanan Gempa untuk Struktur Bangunan Gedung dan Nongedung. SNI 1726:2019. Jakarta (ID): BSN.

[BSN] 2019b. Persyaratan Beton Struktural untuk Bangunan Gedung. SNI 2847:2019. Jakarta (ID): BSN.

Cornelis R, Bunganaen W, Tay BHU. 2014. Analisis perbandingan gaya geser tingkat, gaya geser dasar, perpindahan tingkat dan simpangan antar tingkat akibat beban gempa berdasarkan peraturan gempa SNI 1726-2002 dan SNI 1726-2012. Jurnal Teknik Sipil. 3(2):205-216.

[DepPU] Departemen Pekerjaan Umum. 1987. Pedoman Perencanaan Pembebanan unruk Rumah dan
Gedung (PPPURG). SKBI 1.353.1987. Jakarta (ID): Deparatemen PU.

Fauzan SA, Erizal, Sapei A. 2015. Evaluasi struktur gedung $\mathrm{X}$ di Jakarta berdasarkan SNI 03-17262012 ketahanan gempa untuk struktur gedung. Jurnal Rekayasa Sipil. 4(2):62-75.

Fauziah L, Sumajouw MDJ. Dapas SO. Windah RS. 2013. Pengaruh penempatan dan posisi dinding geser terhadap simpangan bangunan beton bertulang bertingkat banyak akibat beban gempa. Jurnal Sipil Statik. 1(7):466-472.

[FEMA] Federal Emergency Management Agency. 2000. Prestandard and Commentary for the Seismic Rehabilitation of Buildings. FEMA 365. Virginia (US): American Society of Civil Engineers.

Harahap MF, Fauzan M. 2019. Perilaku dinamik pada struktur Apartemen Metro Galaxy Park terhadap beban gempa. Jurnal Teknik Sipil dan Lingkungan. 4(3):195-206.

Istiono H, Ramadhan AY. 2020. Analisis pengaruh p-delta effect terhadap perbedaan ketinggian struktur gedung tahan gempa (studi kasus: non-highrise building). Jurnal Rekayasa Sipil. 14(3):218-226.

Kuddus MA, Dey PP. 2017. Cost analysis of RCC, steel and composite multi-storied car parking subjected to high wind exposure in Bangladesh. Civil Engineering Journal. 3(2):95-104. Liando FJ, Dapas SO, Wallah SE. 2020. Perencanaan struktur beton bertulang gedung kuliah 5 lantai. Jurnal Sipil Statik. 8(4):471-482.

Marsh K. 2014. Autodesk Robot Structural Analysis Professional 
2015: Essentials. Somerville (US): Marsh API.

Maulana R, Yudha AP, Nuroji N, Wibowo H. 2017. Perencanaan gedung pascasarjana Poltekes Semarang. Jurnal Karya Teknik Sipil. 6(1):419-427.

Partono W, Irsyam M, Prabandiyani SRW, Maarif S. 2013. Aplikasi metode HVSR pada perhitungan faktor amplifikasi tanah di Kota Semarang. Jurnal Media Komunikasi Teknik Sipil. 19(2):125-134.

[PUSGEN] Tim Pusat Studi Gempa Nasional. 2017. Peta Sumber dan Bahaya Gempa Indonesia Tahun Jakarta (ID): Kementrian Pekerjaan Umum dan Perumahan Rakyat.

Rahmantyo A, Andayani R. 2019. Analisis story drift dan kondisi sendi plastis berbasis performa pada gedung bertingkat dengan konfigurasi struktur persegi panjang, U, L, H, dan T. Jurnal Media Komunikasi Teknik Sipil. 25(1):38-47.

Rendra R, Kurniawandy A, Djauhari Z. 2015. Kinerja struktur akibat beban gempa dengan metode respon spektrum dan time history (studi kasus: Hotel SKA Pekanbaru). Jurnal Online Mahasiswa (JOM) Bidang Teknik dan Sains. 2(2):1-15.

Rudiyanto B. 2018. Analisis Efisiensi Penggunaan Balok Baja Bukaan Bulat (Cellular Beam) pada Struktur Atap (Studi Kasus: Mall Botania Two, Batam) [tesis]. Batam: Universitas Internasional Batam. 